Bentham open
CrossMark
Content list available at: www.benthamopen.com/TOMICROJ/
DOI: $10.2174 / 1874285801711010105$

LETTER

\title{
Effects of Prenatal Consumption of Caprine Milk Oligosaccharides on Mice Mono-associated with Bifidobacterium Bifidum (AGR2166)
}

Caroline Thum ${ }^{1,2, *}$, Kikuji Itoh $^{3}$, Wayne Young ${ }^{1,2}$, Adrian Cookson ${ }^{2,4}$, Warren McNabb ${ }^{2}$ and Nicole $\operatorname{Roy}^{1,2}$

${ }^{I}$ Food Nutrition \& Health Team, Food \& Bio-based Products Group, AgResearch Grasslands, Palmerston North 4442, New Zealand

${ }^{2}$ Riddet Institute, Massey University, Palmerston North 4442, New Zealand

${ }^{3}$ Laboratory of Veterinary Public Health, Graduate School of Agricultural and Life Sciences, University of Tokyo, Tokyo 113-0033, Japan

${ }^{4}$ Food Assurance \& Meat Quality Team, Food and Bio-based Products Group, Hopkirk Institute, Palmerston North, New Zealand

\section{Abstract:}

\section{Background:}

Prenatal consumption of oligosaccharides are associated with changes in the maternal gastrointestinal tract (GIT) microbiota with health consequences for the offspring. It has previously been demonstrated that caprine milk oligosaccharides (CMO) stimulate the growth and fermentation rate of Bifidobacterium bifidum AGR2166.

\section{Objective:}

The objective of this study was to examine the effects of B. bifidum AGR2166 and prenatal consumption of CMO, alone or in combination, on the dam's large intestine, foetal development and ability of B. bifidum to translocate from the gastrointestinal lumen to organs and foetal membranes.

\section{Method:}

Germ-free BALB/c mice, inoculated with B. bifidum AGR2166 or anaerobic phosphate buffer, were fed either diet supplemented with CMO or with galacto-oligosaccharide. Pregnant mice were euthanised 1 to 3 days before the expected delivery date and samples collected for analysis.

\section{Results:}

Dietary CMO, regardless of bifidobacterial inoculation was shown to increase GIT weight and to reduce foetal weight compared to galacto-oligosaccharide-fed dams. B. bifidum AGR2166 DNA was detected in the mesenteric lymph nodes, liver, plasma and placenta of the dam by amplification of the bifidobacterial $16 \mathrm{~S}$ rRNA gene.

\section{Conclusion:}

B. bifidum AGR2166 DNA was detected in maternal organs, however there is no indication that live bifidobacteria was able to translocate during pregnancy. Further studies using conventionally-raised mouse models will develop a deeper understanding of the interactions between dietary $\mathrm{CMOF}$, the host, and bacteria.

\footnotetext{
* Address correspondence to this author at the Food Nutrition \& Health Team, Food \& Bio-based Products Group, AgResearch Grasslands, Palmerston North 4442, New Zealand; Tel: +64 6 3568019; Fax: +64 6 3518032; E-mail: Caroline.thum@agresearch.co.nz
} 
Keywords: Maternal diet, Caprine milk oligosaccharides, Bifidobacteria, Germ-free mice, Mono-associated, Prebiotic.

\section{INTRODUCTION}

Prenatal consumption of a specific prebiotic and/or probiotic is associated with changes in the maternal gastrointestinal tract (GIT) microbiota [1] and metabolism [2], with implications for both maternal and neonatal health [3]. These effects are likely to involve selective fermentation of commensal bacteria, release of fermentative products, improvement of barrier function of the GIT epithelium and mucosal immune regulation. Evidence that orally administered probiotic strains to the mothers can translocate from the GIT to the umbilical cord blood [4] and meconium [5] also suggest direct effect of maternal GIT on the foetus development.

Caprine milk oligosaccharides (CMO) are potential prebiotic oligosaccharides, with some degree of similarity to those found in human milk oligosaccharides (HMO) [6]. HMO are natural oligosaccharides known to stimulate the establishment of the neonatal GIT microbiota by accelerating the development and the maturation of the neonate's GIT (morphologically and immunologically [7];). We have previously demonstrated that CMO enriched fraction (CMOF) was able to stimulate in vitro the growth and fermentation rate of bifidobacteria strains isolated from the faeces of exclusively breast-fed infants [8]. Of the isolated strains, Bifidobacterium bifidum (AGR2166) were shown to efficiently ferment CMOF [8] producing acetic and lactic acid. Another study, from our group showed that consumption of $\mathrm{CMO}$ by the dams during gestation and lactation improved the development of the pups, and increased the relative abundance of bifidobacteria and butyric acid in the colon, at weaning [9].

Therefore, the objective of this study was to examine the effects dietary CMOF alone or in combination with inoculation of B. bifidum (AGR2166) on maternal GIT morphology, caecal fermentation and foetal development. The ability of $B$. bifidum to translocate from the GIT lumen to the maternal organs and foetal membranes was also investigated.

\section{METHODS}

\section{Animals and Diet}

This study was approved by the Tokyo University Animal Ethics committee, Tokyo, Japan. Germ-free (GF) BALB/c mice (32 female and 16 male) (Laboratory of Veterinary Public Health, The University of Tokyo), between 15 and 23 weeks of age, were housed in a vinyl isolator sterilised with $2 \%$ peracetic acid under normal conditions $(12 \mathrm{~h}$ light/dark cycle). Two different diets, AIN-76A supplemented with CMOF containing 0.9\% CMO (treatment; CMO diet) and AIN-76A supplemented with galacto-oligosaccharide (GOS), at the same concentration that are present in the CMOF (GOS diet), were formulated to meet mouse nutritional requirements (Oriental Yeast Co. Ltd., Japan) (Table 1). Maltodextrin concentration was adjusted in the CMO and GOS-modified diets for nutritional balance. Dietary oligosaccharide composition was analysed by liquid chromatography-mass spectrometry and dietary GOS was analysed by high performance ion chromatography as previously described [6].

Table 1. GOS and caprine milk oligosaccharide diet composition based on AIN-76A diet.

\begin{tabular}{|c|c|c|}
\hline Diet composition (g/Kg) & GOS & CMO \\
\hline Casein & 200 & 200 \\
\hline Corn oil & 50 & 50 \\
\hline Cellulose, BW200 & 50 & 50 \\
\hline DL-Methionine & 3 & 3 \\
\hline Mineral Mix S10001 & 35 & 35 \\
\hline Vitamin Mix V10001 & 10 & 10 \\
\hline Choline Bitartrate & 2 & 2 \\
\hline Corn Starch & 500 & 500 \\
\hline Maltodextrin & 128.1 & 118.1 \\
\hline Test components (g/kg) & GOS & CMO \\
\hline GOS & 1.8 & 2.0 \\
\hline CMO & 0 & 9 \\
\hline
\end{tabular}

Mice were randomly assigned to 4 groups (GF/GOS diet, GF/CMO diet, Bifidobacteria/GOS diet, Bifidobacteria/CMO diet) of twelve mice each (eight females and four males). Mice were inoculated with B. bifidum 
AGR2166 (0.5 mL of bacterial suspension containing approximately $\left.10^{8} \mathrm{CFU} / \mathrm{mL}\right)$, or $0.5 \mathrm{~mL}$ of anaerobic phosphate buffer solution via oral gavage and fed either GOS or CMO diet. Microbiological analysis of fresh faecal samples collected on days 3,10 and 17 of the experimental period and caecal digesta after euthanasia was used to evaluate $B$. bifidum AGR2166 colonisation.

The mice were euthanised 1 to 3 days before the expected date that pups would be delivered and samples were collected for analysis. Maternal organs were weighed and blood, liver, large intestine mesenteric lymph nodes (MLN), uterus, amniotic fluid, foetus and foetal blood were aseptically collected. Approximately half of each sample was stored at $-80^{\circ} \mathrm{C}$ for DNA extraction, and half plated on a BL agar plate (a selective medium for Bifidobacterium spp [10]). Plates were incubated anaerobically at $37^{\circ} \mathrm{C}$ and $\mathrm{B}$. bifidum growth assessed after $48 \mathrm{~h}$. The GIT was removed, and the length-to-weight ratio recorded prior to full dissection. Proximal sections of the colon were collected for histological assessment of the colonic crypt length and goblet cell numbers.

\section{Colon Histology}

Formalin fixed transverse, paraffin embedded sections of the colon were stained with haematoxylin and eosin. Morphology measurements were performed using bright field microscopy at 200 times magnification and Image-Pro Plus 4.0 (MediaCybernetics, Bethesda, MD, USA). Crypt lengths were determined by measuring an average of 80 random fully longitudinally sectioned crypts and number of goblet cells was determined by counting goblet cells in an average of 30 crypts per mouse.

\section{Caecal Short Chain Fatty Acids}

The concentrations of acetic acid, propionic acid, ethyl-butyric acid, butyric acid, isovaleric acid, valeric acid, formic acid, lactic acid and succinic acid in the caecal digesta were measured using a Shimadzu RID 10A HPLC

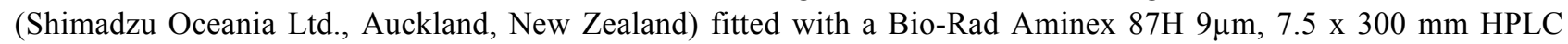
column, as previously described [8].

\section{Isolation of Bifidobacteria DNA}

Total DNA was extracted from maternal plasma, MLN, spleen, liver, placenta, amniotic fluid, foetus and caecum content using DNeasy Blood \& Tissue Kit (Qiagen, Biolab NZ) according to the manufacturer's instructions for the extraction of Gram-positive bacterial DNA. Samples were boiled for $1 \mathrm{~min}$ or transferred to a tube containing $0.3 \mathrm{~g}$ of sterile $0.1 \mathrm{~mm}$ diameter zirconium beads (Sigma-Aldrich) and shaken in a mini bead beater (Biospec Products, Bartlesville, OK, USA) set at maximum for $45 \mathrm{~s}$, followed by centrifugation at 13,000 X g for $1 \mathrm{~min}$ before being added to the DNeasy Mini spin column. From the isolated genomic DNA, the bifidobacterial 16S rRNA gene was amplified with bif 164 and bif 662 primers [11] by PCR using a previously described method [8]. The presence of bacterial contamination in maternal plasma and liver was determined by PCR amplification of the 16S rRNA gene using the universal bacterial primers fD1 and rD1 [12].

\section{Statistical Analysis}

Unbalanced ANOVA was used to compare treatments (GenStat V15). The different rate of bifidobacteria translocation between treatments was evaluated by a binomial test. Statistically different means were determined using the post hoc LSD test at $5 \%$.

\section{RESULTS}

\section{Bifidobacteria Detection}

Bifidobacterial numbers recovered from faeces remained stable $\left(10^{8} \mathrm{CFU}\right.$ per gram of faeces) during the experimental period. Bifidobacterial numbers, in dam faeces, were not increased by the consumption of CMO during the experimental period. The presence of B. bifidum in the caecum of inoculated mice was also confirmed by amplification of the B. bifidum 16s rRNA gene. No amplification of this gene was observed in digesta from GF mice. No contamination, with other bacterial strains, were detected by PCR amplification of the 16S rRNA gene using the universal bacterial primers $\mathrm{fD} 1$ and $\mathrm{rD} 1$ in both GF and B. bifidum inoculated mice. 


\section{Dams and Litters}

Of the eight female mice originally mated in each treatment group, few were pregnant by the end of mating period; GF/GOS, 1; GF/CMO, 3; Bifidobacteria/GOS, 4; Bifidobacteria/CMO, 3. Due to the low mating success in the experimental group GF/GOS, no comparisons were drawn between these mice and the other treatment groups.

\section{Body and Organs Weights and Histology}

There was no evidence that diet, bifidobacteria or the interaction between diet and bifidobacteria inoculation affected maternal colon morphology and maternal body, uterus, spleen, liver and MLN weight. Dams fed the CMO diet, however, had increased GIT wet weight and lower foetus wet weight compared to dams fed the GOS diet, regardless of inoculation status (Table 2). Dams mono-associated with bifidobacteria had lower GIT weight and conceived a higher number of foetuses compared to GF mice, regardless of the diet (Table 3). Since there was only one observation for GF mice fed the GOS diet, no variation for this treatment could be estimated and the effects of diet and bifidobacteria were influenced by this single observation.

Table 2. Effect of diet on dam absolute and normalised body weight, organ weight colon crypt length and goblet cells number and gastrointestinal tract length (mean $\pm \mathrm{SE}$, expressed in $\mathrm{mg} / \mathrm{g}$ or $\mathrm{cm} / \mathrm{g}$ total body weight).

\begin{tabular}{|c|c|c|c|c|}
\hline Treatments* & GOS & CMO & P-value & LSD \\
\hline Body weight $(\mathrm{g})$ & $40.0 \pm 1.1$ & $42.7 \pm 11$ & 0.3 & 4.2 \\
\hline Uterus weight $(\mathrm{mg} / \mathrm{g})$ & $183 \pm 17$ & $170 \pm 12$ & 0.2 & 52 \\
\hline Number of foetus & $5.7 \pm 0.4$ & $6.2 \pm 0.5$ & 0.4 & 1.4 \\
\hline Foetus weight $(\mathrm{mg} / \mathrm{g})$ & $131 \pm 20$ & $98 \pm 8$ & 0.03 & 44 \\
\hline Spleen weight $(\mathrm{mg} / \mathrm{g})$ & $2 \pm 0.07$ & $2 \pm 0.09$ & 0.7 & 0.3 \\
\hline Liver weight $(\mathrm{mg} / \mathrm{g})$ & $4.8 \pm 0.3$ & $4.4 \pm 0.2$ & 0.2 & 1.0 \\
\hline MLN weight $(\mathrm{mg} / \mathrm{g})$ & $0.4 \pm 0.04$ & $0.6 \pm 0.1$ & 0.1 & 0.3 \\
\hline GIT length $(\mathrm{cm} / \mathrm{g})$ & $1.31 \pm 1.3$ & $1.35 \pm 1.4$ & 0.1 & 0.1 \\
\hline GIT weight $(\mathrm{mg} / \mathrm{g})$ & $124 \pm 10$ & $136 \pm 4$ & 0.03 & 18 \\
\hline Goblet cells number & $22.6 \pm 1.8$ & $19.6 \pm 1.0$ & 0.1 & 4.4 \\
\hline Crypt size $(\mu \mathrm{m})$ & $184.2 \pm 7.5$ & $175.4 \pm 3.5$ & 0.2 & 17.7 \\
\hline
\end{tabular}

* GOS and CMOF containing diet were identified as GOS and CMO, respectively ( $\mathrm{n}=\mathrm{GOS}, 5 ; \mathrm{CMO}, 6)$

Table 3. Effect of bifidobacteria on body weight, organ weight, colon crypt length and goblet cells number and gastrointestinal tract length (mean $\pm \mathrm{SE}$, expressed in $\mathrm{mg} / \mathrm{g}$ or $\mathrm{cm} / \mathrm{g}$ total body weight).

\begin{tabular}{|c|c|c|c|c|}
\hline Treatments* & GF & Bifidobacteria & P-value & LSD \\
\hline Body weight $(\mathrm{g})$ & $39.8 \pm 1.5$ & $42.4 \pm 1.0$ & 0.1 & 4.4 \\
\hline Uterus weight $(\mathrm{mg} / \mathrm{g})$ & $155 \pm 14$ & $188 \pm 13$ & 0.2 & 54 \\
\hline Number of foetus & $5.0 \pm 0.4$ & $6.6 \pm 0.3$ & 0.003 & 1.5 \\
\hline Foetus weight $(\mathrm{mg} / \mathrm{g})$ & $90 \pm 6$ & $126 \pm 16$ & 0.1 & 47 \\
\hline Spleen weight $(\mathrm{mg} / \mathrm{g})$ & $2.08 \pm 0.04$ & $2.02 \pm 0.09$ & 0.6 & 0.3 \\
\hline Liver weight $(\mathrm{mg} / \mathrm{g})$ & $4.3 \pm 0.3$ & $4.8 \pm 0.2$ & 0.4 & 1.1 \\
\hline MLN weight $(\mathrm{mg} / \mathrm{g})$ & $0.6 \pm 0.1$ & $0.5 \pm 0.05$ & 0.6 & 0.3 \\
\hline GIT length $(\mathrm{cm} / \mathrm{g})$ & $1.39 \pm 0.04$ & $1.30 \pm 0.03$ & 0.1 & 0.1 \\
\hline GIT weight $(\mathrm{mg} / \mathrm{g})$ & $147 \pm 3$ & $121 \pm 6$ & 0.02 & 19 \\
\hline Goblet cells number & $18.5 \pm 1.1$ & $22.3 \pm 1.2$ & 0.07 & 4.3 \\
\hline Crypt size $(\mu \mathrm{m})$ & $170.8 \pm 2.6$ & $184.3 \pm 5.2$ & 0.1 & 16.7 \\
\hline
\end{tabular}

* Treatments are identified as GF and Bifidobacteria for non-inoculated and inoculated mice respectively (n= Bifidobacteria, 7; GF, 4)

\section{Caecal Short Chain Fatty Acids}

Formic acid was only detected in inoculated dams fed GOS diet (Bifidobacteria/GOS, $177 \pm 10.0$, mean $(\mu \mathrm{mol} / \mathrm{g}) \pm$ $\mathrm{SE})$. Succinic acid concentration was increased $(\mathrm{P}=0.03)$ in the caecum of GF dams fed CMO compared to inoculated dams (GF/GOS, nd; GF/CMO, $163.4 \pm 24$; Bifidobacteria/GOS, $3.8 \pm 0.8$; Bifidobacteria/CMO, $21.9 \pm 5$, mean $(\mu \mathrm{mol} / \mathrm{g}) \pm \mathrm{SE})$. Lactic acid was detected in higher concentrations $(\mathrm{P}=0.02)$ in the caecum of the dams inoculated with bifidobacteria and fed GOS diet compared to those fed the CMO diet (GF/GOS, nd; GF/CMO, $1.3 \pm 0.8$; Bifidobacteria/GOS, $274.7 \pm 28$; Bifidobacteria/CMO, 138.7 \pm 8 , mean $(\mu \mathrm{mol} / \mathrm{g}) \pm \mathrm{SE})$. 


\section{Bifidobacterial Translocation}

No viable bacteria, as determined by culture, were detected in the maternal organs after $48 \mathrm{~h}$ incubation in anaerobic conditions. However, B. bifidum AGR2166 DNA was detected in samples from GOS-fed dams (1 liver, 2 plasma, 3 placenta) and CMO-fed dams ( 2 MLN, 2 liver, 3 plasma and 3 placenta) by amplification of the bifidobacterial $16 \mathrm{~S}$ rRNA gene. In animals that received the CMO diet, bifidobacteria DNA was detected in a greater number of samples when compared to GOS fed animals $(\mathrm{P}=0.01)$. Only non-specific bands were detected in GF dam's samples.

\section{DISCUSSION}

To our knowledge, this is the first study to report the effects of an oligosaccharide-enriched diet fed to monoassociated dams. The low levels of fecundity observed in all treatments restricted the number of samples analysed in this study. Reduced fecundity and implantation rate have been reported as limitations for the use of GF mice as a model [13]. GF mice inoculated with B. bifidum AGR2166 had increased number of foetuses, in agreement with a previous study where enhanced implantation rate was observed in GF mice following bacterial colonisation [14]. CMO-fed dams had reduced foetal weight compared to GOS-fed dams, however, most GOS-fed dams analysed were inoculated with bifidobacteria. Bifidobacteria colonisation improves nutrient absorption, therefore increased nutrients may reach the foetus thereby improving growth.

CMO diet did not increase dam's faecal bifidobacterial numbers during experimental period. This was also reported in a previous study were consumption of CMO by the dams during gestation and lactation did not increased the relative abundance of bifidobacteria in the colon but increased in the colon of the offspring at weaning (9).

The consumption of CMO, regardless of bifidobacterial inoculation, was shown to increase GIT weight. Dietary fibre $[15,16]$ increases water retention and mucin secretion in the small intestine and colon as a consequence of both short chain fatty acid (SCFA) production [17] and mechanical stimulation by increased faecal mass [18]. Bacterial colonisation may have opposite effects to that, by decreasing caecal enlargement due to the metabolism of resistant carbohydrates, as observed in this study by the oral administration of B. bifidum AGR2166.

B. bifidum AGR2166 preferentially produced lactic acid and formic acid; reaching higher concentrations when mice where fed GOS diet. Specific rate of sugar consumption plays an important role in the ratio of the final metabolites produced by Bifidobacterium spp. If bifidobacteria consume the energy source fast, larger amounts of lactic acid and relatively smaller amounts of acetic acid, formic acid, and ethanol are produced [19]. A higher concentration of succinic acid, was detected in the GF mice fed CMO compared to inoculated mice. Trace amounts of SCFA have previously been reported in GF mice [20], and it is likely that these arise from cellular metabolism in the mice as a result of the oligosaccharides in the CMO diet.

B. bifidum AGR2166 DNA was detected in the maternal plasma, liver, MLN and placenta of inoculated mice. Bifidobacteria administered orally to GF mice have been previously reported to translocate to MLN, spleen, liver, lungs and kidneys [21, 22], supporting these findings. Bacterial DNA was detected in a higher number of samples from CMO fed dams compared to those fed the GOS diet. Although this is in agreement with previous work where dietary fibre was shown to increase bacterial translocation [23], no qPCR analysis was done to confirm that. The non-detection of bacterial DNA in the amniotic fluid and foetus or viable bacteria, in all dams' organs, may be due to the low levels of bifidobacteria in these samples. Human and laboratory mammal foetuses swallow amniotic fluid, prior to the presence of milk in the GIT, therefore, bacteria in the amniotic fluid if any, are likely to be found in the foetal GIT. Rather than an inoculum for GIT colonisation, the low levels of bacteria previously reported in umbilical cord blood, amniotic fluid, placenta and foetal membranes are likely to stimulate the development of GIT mucosal immune system of the foetus [24], in preparation for life outside the uterus.

In conclusion, consumption of CMO diet, regardless of bifidobacterial inoculation, did not modify maternal caecal fermentation and colon morphology. The reduction on foetal weight attributed to the CMO diet needs to be evaluated with caution due to the low number of animals. Further studies using conventionally-raised mouse models will develop a deeper understanding of the interactions between dietary CMOF, the host, and bacteria.

\section{ETHICS APPROVAL AND CONSENT TO PARTICIPATE}

Not applicable. 


\section{HUMAN AND ANIMAL RIGHTS}

Human did not participate in this research. All animal research procedures followed were in accordance with the standards set forth in the 8th Edition of Guide for the Care and Use of Laboratory Animals (http:// grants.nih.gov/grants/olaw/Guide-for-the-care-and-use-of-laboratory-animals.pdf) published by the National Academy of Sciences, The National Academies Press, Washington DC, United States of America.

\section{CONSENT FOR PUBLICATION}

Not applicable.

\section{CONFLICT OF INTEREST}

The authors declare no conflict of interest. This work was funded by Ministry of Business, Innovation and Employment, New Zealand (C10X0907), the Riddet Institute Centre of Research Excellence and AgResearch Limited.

\section{ACKNOWLEDGEMENTS}

Caroline Thum acknowledges the Ministry of Business, Innovation and Employment IBF, New Zealand (C10X0907; C10X1003), the Riddet Institute Centre of Research Excellence and AgResearch for the funding and the PhD Scholarship.

\section{REFERENCES}

[1] Hallam MC, Barile D, Meyrand M, German JB, Reimer RA. Maternal high-protein or high-prebiotic-fiber diets affect maternal milk composition and gut microbiota in rat dams and their offspring. Obesity (Silver Spring) 2014; 22(11): 2344-51. [http://dx.doi.org/10.1002/oby.20849] [PMID: 25056822]

[2] Taghizadeh M, Hashemi T, Shakeri H, et al. Synbiotic food consumption reduces levels of triacylglycerols and VLDL, but not cholesterol, LDL, or HDL in plasma from pregnant women. Lipids 2014; 49(2): 155-61. [http://dx.doi.org/10.1007/s11745-013-3867-2] [PMID: 24271261]

[3] Desbuards N, Gourbeyre P, Haure-Mirande V, Darmaun D, Champ M, Bodinier M. Impact of perinatal prebiotic consumption on gestating mice and their offspring: a preliminary report. Br J Nutr 2012; 107(9): 1245-8. [PMID: 21906405]

[4] Jiménez E, Fernández L, Marín ML, et al. Isolation of commensal bacteria from umbilical cord blood of healthy neonates born by cesarean section. Curr Microbiol 2005; 51(4): 270-4. [http://dx.doi.org/10.1007/s00284-005-0020-3] [PMID: 16187156]

[5] Jiménez E, Marín ML, Martín R, et al. Is meconium from healthy newborns actually sterile? Res Microbiol 2008; 159(3): 187-93. [http://dx.doi.org/10.1016/j.resmic.2007.12.007] [PMID: 18281199]

[6] Thum C, Cookson A, McNabb W, Roy CN, Otter D. Composition and enrichment of caprine milk oligosaccharides from New Zealand Saneen goat cheese whey. J Food Compos Anal 2015; 42: 30-7. [http://dx.doi.org/10.1016/j.jfca.2015.01.022]

[7] Kobata A. Structures and application of oligosaccharides in human milk. Proc Jpn Acad, Ser B, Phys Biol Sci $2010 ; 86(7)$ : $731-47$. [http://dx.doi.org/10.2183/pjab.86.731] [PMID: 20689231]

[8] Thum C, Roy NC, McNabb WC, Otter DE, Cookson AL. In vitro Fermentation of caprine milk oligosaccharides by bifidobacteria isolated from breast-fed infants. Gut Microbes 2015; 6(6): 352-63. [http://dx.doi.org/10.1080/19490976.2015.1105425] [PMID: 26587678]

[9] Thum C, McNabb WC, Young W, Cookson AL, Roy NC. Prenatal caprine milk oligosaccharide consumption affects the development of mice offspring. Mol Nutr Food Res 2016; 60(9): 2076-85.

[http://dx.doi.org/10.1002/mnfr.201600118] [PMID: 27067267]

[10] Nebra Y, Blanch AR. A new selective medium for Bifidobacterium spp. Appl Environ Microbiol 1999; 65(11): 5173-6. [PMID: 10543841]

[11] Kok RG, de Waal A, Schut F, Welling GW, Weenk G, Hellingwerf KJ. Specific detection and analysis of a probiotic Bifidobacterium strain in infant feces. Appl Environ Microbiol 1996; 62(10): 3668-72. [PMID: 8837422]

[12] Weisburg WG, Barns SM, Pelletier DA, Lane DJ. 16S ribosomal DNA amplification for phylogenetic study. J Bacteriol 1991; 173(2): 697-703. [http://dx.doi.org/10.1128/jb.173.2.697-703.1991] [PMID: 1987160]

[13] Coates ME. Gnotobiotic animals in research: their uses and limitations. Lab Anim 1975; 9(4): 275-82 [http://dx.doi.org/10.1258/002367775780957296] [PMID: 1107656] 
[14] Shimizu K, Muranaka Y, Fujimura R, Ishida H, Tazume S, Shimamura T. Normalization of reproductive function in germfree mice following bacterial contamination. Exp Anim 1998; 47(3): 151-8. [http://dx.doi.org/10.1538/expanim.47.151] [PMID: 9816490]

[15] Cabotaje LM, Shinnick FL, Lopéz-Guisa JM, Marlett JA. Mucin secretion in germfree rats fed fiber-free and psyllium diets and bacterial mass and carbohydrate fermentation after colonization. Appl Environ Microbiol 1994; 60(4): 1302-7. [PMID: 8017918]

[16] Satchithanandam S, Vargofcak-Apker M, Calvert RJ, Leeds AR, Cassidy MM. Alteration of gastrointestinal mucin by fiber feeding in rats. J Nutr 1990; 120(10): 1179-84.

[PMID: 2170600]

[17] Barcelo A, Claustre J, Moro F, Chayvialle JA, Cuber JC, Plaisancié P. Mucin secretion is modulated by luminal factors in the isolated vascularly perfused rat colon. Gut 2000; 46(2): 218-24 [http://dx.doi.org/10.1136/gut.46.2.218] [PMID: 10644316]

[18] Ten Bruggencate SJ, Bovee-Oudenhoven IM, Lettink-Wissink ML, Katan MB, van der Meer R. Dietary fructooligosaccharides affect intestinal barrier function in healthy men. J Nutr 2006; 136(1): 70-4. [PMID: 16365061]

[19] Van der Meulen R, Adriany T, Verbrugghe K, De Vuyst L. Kinetic analysis of bifidobacterial metabolism reveals a minor role for succinic acid in the regeneration of $\mathrm{NAD}^{+}$through its growth-associated production. Appl Environ Microbiol 2006; 72(8): 5204-10. [http://dx.doi.org/10.1128/AEM.00146-06] [PMID: 16885266]

[20] Høverstad T, Midtvedt T. Short-chain fatty acids in germfree mice and rats. J Nutr 1986; 116(9): 1772-6. [PMID: 3761032]

[21] Yamazaki S, Machii K, Tsuyuki S, Momose H, Kawashima T, Ueda K. Immunological responses to monoassociated Bifidobacterium longum and their relation to prevention of bacterial invasion. Immunology 1985; 56(1): 43-50. [PMID: 4043995]

[22] Romond MB, Haddou Z, Mielcareck C, Romond C. Bifidobacteria and human health: regulatory effect of indigenous bifidobacteria on Escherichia coli intestinal colonization. Anaerobe 1997; 3(2-3): 131-6. [http://dx.doi.org/10.1006/anae.1997.0089] [PMID: 16887577]

[23] Deitch EA. Bacterial translocation: the influence of dietary variables. Gut 1994; 35(1)(Suppl.): S23-7. [http://dx.doi.org/10.1136/gut.35.1_Suppl.S23] [PMID: 8125385]

[24] Wagner CL, Taylor SN, Johnson D. Host factors in amniotic fluid and breast milk that contribute to gut maturation. Clin Rev Allergy Immunol 2008; 34(2): 191-204.

[http://dx.doi.org/10.1007/s12016-007-8032-3] [PMID: 18330727]

(C) 2017 Thum et al.

This is an open access article distributed under the terms of the Creative Commons Attribution 4.0 International Public License (CC-BY 4.0), a copy of which is available at: https://creativecommons.org/licenses/by/4.0/legalcode. This license permits unrestricted use, distribution, and reproduction in any medium, provided the original author and source are credited. 